\title{
Is Possible the Use of RPE Scale in Coordination Skill Sport: Skateboarding Experience
}

\author{
Tornaghi Michele', Lovecchio Nicola ${ }^{2}$ \\ ${ }^{1}$ Uman Performance Laboratory, MAPEI Sport Research Centre, Olgiate Olona, Italy \\ ${ }^{2}$ Department of Biomedical Science for Health, University of Milan, Milan, Italy \\ Email: nicola.lovecchio@unimi.it
}

How to cite this paper: Michele, T. and Nicola, L. (2017) Is Possible the Use of RPE Scale in Coordination Skill Sport: Skateboarding Experience. Open Access Library Journal, 4: e3465.

https://doi.org/10.4236/oalib.1103465

Received: February 17, 2017

Accepted: March 12, 2017

Published: March 15, 2017

Copyright $\odot 2017$ by authors and Open Access Library Inc.

This work is licensed under the Creative Commons Attribution International License (CC BY 4.0).

http://creativecommons.org/licenses/by/4.0/

\section{(c) †) Open Access}

\begin{abstract}
The Rate of Perceived Exertion scale was widely used in monitoring training session but the feasibility of this approach was not verified in skateboarding training or competition. Thus, the purpose of this brief report was the assessment of a skateboarder using the Rate of Perceived Exertion. Nine months of conditioning about a professional skater were collected after each session. The Rate of Perceived Exertion was interviewed, also, after the most important competition day. Furthermore, the internal training load was evaluated using the indication proposed in scientific community. During the first period of training, the training load was similar than the value obtained in the most official competition of the season. The mean value of Rate of Perceived Exertion collected during the training session was similar to the results declared during the competition. The value of training load in this professional skater was similar to other professional athletes. The trainer could find important practical implication such as the statement that the skater did not reach, on average, the level of overtraining. Further studies could improve the assessment using more detailed stratification about the kind of condition and about the physiological parameters.
\end{abstract}

\section{Subject Areas}

Sports Science

\section{Keywords}

RPE, Skateboard, Training Load

\section{Introduction}

The RPE scale [1] [2] is a tool widely used in training session or rehabilitation program [3] [4] [5] and becomes a valid visual analogic scale to monitor the 
internal load [6]. Indeed, in the lasts years the session RPE was used to verify the trainig program [7] and avoid the overtraining (arbitrary units over than 600 in one week; [8] [9]) in several sport. Examples are proposed in soccer [10], basketball, [11], rugby [12], water polo [13], gymnastics [14], swimming [15], diving [16], endurance training [17] [18] or for clinical assessment [19] [20] and daily living activity [17].

To the best of our knowledge, no assessment was verified in individual sport where the coordination skills were strongly implicated and where although the performance (using a tool) is played in closed skill context and in a known routine, the final results could be considered as an open skill outcome.

In this point, a pilot assessment of skating practice was carried out. In particular, a professional skater was assessed using RPE scale during training session and official competition to verify the reliability of the RPE in individual and high level coordination skill performance.

\section{Methods}

\subsection{Partecipant}

A professionist male skater (25 years, weight $=178 \mathrm{~cm}$; Height $=64 \mathrm{~kg}$ ) was freely recruited during the sport season $2014 / 15$. He is an expert pratictioner with 13 years of experience (the last 3 as professionist): on average performing $141 \pm 37 \mathrm{~min} /$ die of practice. In particular, he followed a professionist trainer to improve the physical condition in order to obtained the first place in national challange.

The skater was informed about the procedure and the tools involved in the study and the informed consent was obtained.

\subsection{Procedure}

The skater was familiarized with the Borg CR-10 scale as indicated by Borg [3] during preliminary training session in the month of January.

The bouts of conditioning consisted of different kind of training: strenght, power, interval training, high intensity interval training and specific techinical coordination skills using board. Simulation of real challange were also proposed. Table 1 and Table 2 showed an example of week training program. After each day session of training the RPE value was collected (30 min after the end of session, Foster et al., [11]) and then calculated the internal training load $\left(\mathrm{TL}_{\text {session }}\right)$ about all single session. The training load was detected also during official competition performance $\left(\mathrm{TL}_{\text {perf }}\right)$ at the end of the ninth month of conditioning.

\subsection{Data Analysis}

The $\mathrm{TL}_{\text {session }}$ and $\mathrm{TL}_{\text {perf }}$ was calculated using the indication of Foster et al. [11]:

$$
\mathrm{TL}=\mathrm{RPE} \times \text { minute }
$$

After each mesocycle of training the mean value of training load $\left(\mathrm{TL}_{\text {mean }}\right)$ was 
Table 1. The organization of training according to different objective in first period of training (five month). $\mathrm{m}=$ morning; $\mathrm{a}=$ afternoon.

\begin{tabular}{|c|c|c|c|c|c|c|c|c|}
\hline & \multicolumn{2}{|c|}{ Strength } & \multicolumn{2}{|c|}{ Interval training } & \multicolumn{2}{|c|}{ Specific skill } & \multicolumn{2}{|c|}{ Trick simulation } \\
\hline & $\mathrm{m}$ & $\mathrm{a}$ & $\mathrm{m}$ & $\mathrm{a}$ & $\mathrm{m}$ & $\mathrm{a}$ & $\mathrm{m}$ & $\mathrm{a}$ \\
\hline Day 1 & $\mathrm{x}$ & & & & & $\mathrm{x}$ & & \\
\hline Day 2 & & & & $\mathrm{x}$ & & & & $\mathrm{x}$ \\
\hline Day 3 & & & & & & $\mathrm{x}$ & & \\
\hline Day 4 & & $\mathrm{x}$ & & & & & $\mathrm{x}$ & \\
\hline Day 5 & & & & & & $\mathrm{x}$ & & \\
\hline Day 6 & & & & $\mathrm{x}$ & & & $\mathrm{x}$ & \\
\hline Day 7 & & & & & & & & $\mathrm{x}$ \\
\hline
\end{tabular}

Table 2. The organization of training according to different objective in second period of training (four month). $\mathrm{m}=$ morning; $\mathrm{a}=$ afternoon.

\begin{tabular}{|c|c|c|c|c|c|c|c|c|c|c|}
\hline & \multicolumn{2}{|c|}{ Core training } & \multicolumn{2}{|c|}{ Power } & \multicolumn{2}{|c|}{$\begin{array}{l}\text { High intensity } \\
\text { interval training }\end{array}$} & \multicolumn{2}{|c|}{ Specific skill } & \multicolumn{2}{|c|}{ Trick simulation } \\
\hline & $\mathrm{m}$ & a & $\mathrm{m}$ & $\mathrm{a}$ & $\mathrm{m}$ & $\mathrm{a}$ & $\mathrm{m}$ & $\mathrm{a}$ & $\mathrm{m}$ & $\mathrm{a}$ \\
\hline Day 1 & & $\mathrm{x}$ & & $\mathrm{x}$ & & & & & & \\
\hline Day 2 & & & & & & $\mathrm{x}$ & & & & \\
\hline Day 3 & $\mathrm{x}$ & & & & & & & $\mathrm{x}$ & & $\mathrm{x}$ \\
\hline Day 4 & & & & $\mathrm{x}$ & & & & & & \\
\hline Day 5 & & & & & & & & & & $\mathrm{x}$ \\
\hline Day 6 & & & & & $\mathrm{x}$ & & & & & $\mathrm{x}$ \\
\hline Day 7 & & & & & & & & & & $\mathrm{x}$ \\
\hline
\end{tabular}

then calculated as the average of internal load perceived by the skater during the session.

\section{Results}

Figure 1 shows the $\mathrm{TL}_{\text {mean }}$ while the corresponding mean $\mathrm{RPE}$ value was $4.2, \mathrm{~s}=$ 0.66 . The $\mathrm{TL}_{\text {perf }}$ during official competition was $1008, \mathrm{~s}=127(\mathrm{RPE}=4.8)$.

\section{Discussion}

This exploratory study aimed to verify the feasability of RPE scale during the performance of particular individual sport. This is the case of skateboarding. Indeed, skaters are implicated in closed skills performance where the coordinative and conditional ability are involved. Furthermore, the use of a board forces the athlete in "tricks" that are not predictable as an absolute closed skill action.

Thus, a professionist skater was assessed using RPE scale [2] and TL method [11] to verify the trend of training session.

The $\mathrm{TL}_{\text {perf }}$ after the official competition (the challenge implicated five eliminatory sessions of three minutes each) was closed to 1000 u.a. co- 


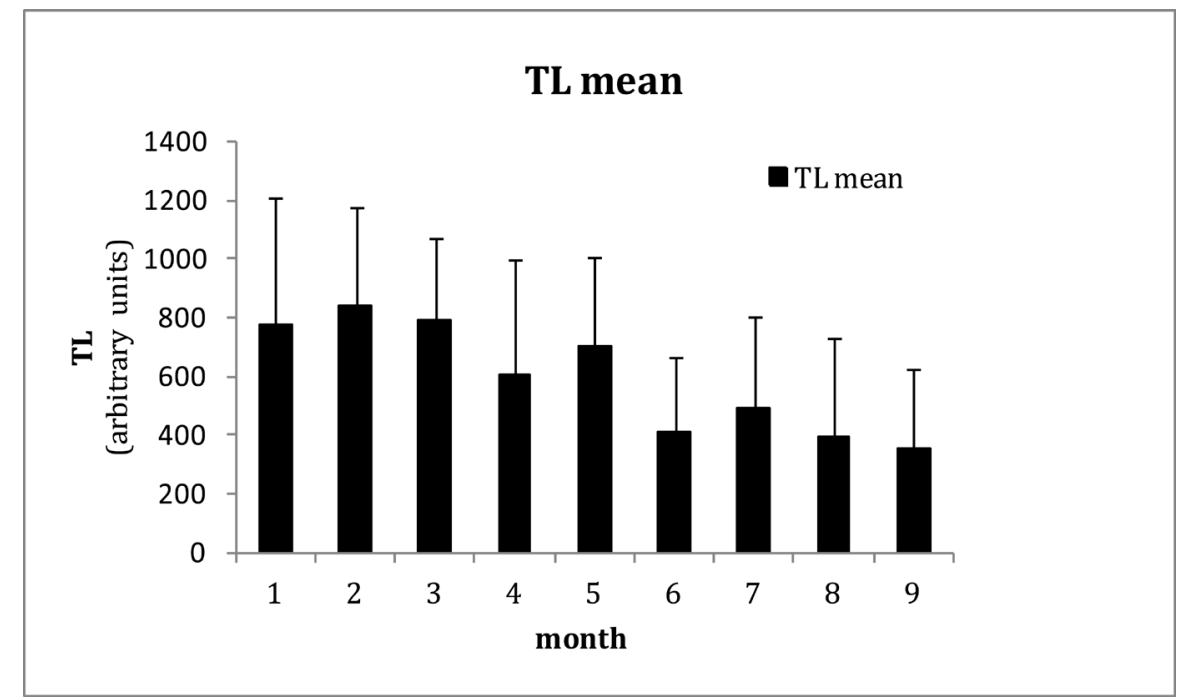

Figure 1. Trend of $\mathrm{TL}_{\text {mean }}$ during the nine month of conditioning.

rresponding to $4.8 \mathrm{RPE}$ value along $225 \mathrm{~min}$. of competition. This high value of TL is similar to the value found in Olympic athletes [7] and very similar to those perceived by the skater in the first phase (first five months) of his training period. It seems a good indication/confermation for trainer that could manage the external load to reach similar stress in their athletes.

The value of $\mathrm{TL}_{\text {mean }}$ during the last four months was less high than the first five months. Indeed, the second part of training was mostly incinerated on competition simulation and technical tricks (Table 1 and Table 2). Also, this statement could be useful for trainer and athletes because they could manage the effort in period near the competitions, in particular, considering that the mean RPE was 4.2: very close to 5.5 found in his official competition and similar to the value collected in runner during the first period ( $10 \%$ of total distance covered, [18] [21]).

Another consideration for trainer is about overtraining status [9]. Indeed, a TL over than 600 u.a. in single session is considered a risky status for continuation in training, in recovery or in general health [9] [22].

Our skater, on average, did not overtake this cut-off during the competition period and this may be another useful parameter for trainer during practical organization load.

The major limitation of this study was the single skater taken into account but the recruitment in this particular sport was hard due to the limited number of professional player. These restricted results, however, could represent indication for skaters and trainers around the world.

Indeed, this pilot study confirmed the feasability of RPE and TL methods to monitoring the contioning session also in particular sport as the skateboarding. Trainers during their session have to reach their skaters to 1000 u.a., because the most important competiton could reach this value and then the possibility to experience this load is important for a competitor's perseverance. The mean RPE during session should be between 4 and 5, and the near the comeptition avoids, 
the long time session or high intensity training to prevent overtraining status.

Further studies will be necessary to improve this pilot analysis. For instance, evaluation of emotive status during competition [23] or cardiac frequency response could be assessed.

\section{References}

[1] Borg, G. (1970) Perceived Exertion as an Indicator of Somatic Stress. Scandinavian Journal of Rehabilitation Medicine, 2, 92-98.

[2] Borg, G.A. (1982) Psychophysical Bases of Perceived Exertion. Medicine \& Science in Sports \& Exercise, 14, 377-381. https://doi.org/10.1249/00005768-198205000-00012

[3] Borg, G. (1998) Borg's Perceived Exertion and Pain Scales. Human Kinetics, Champaign.

[4] Coquart, J.B., Garcin, M., Parfitt, G., Tourny-Chollet, C. and Eston, R.G. (2014) Prediction of Maximal or Peak Oxygen Uptake from Ratings of Perceived Exertion. Sports Medicine, 44, 563-578. https://doi.org/10.1007/s40279-013-0139-5

[5] Groslambert, A. and Mahon, A.D. (2006) Perceived Exertion: Influence of Age and Cognitive Development. Sports Medicine, 36, 911-928. https://doi.org/10.2165/00007256-200636110-00001

[6] Graves, J.E., Martin, A.D., Miltenberger, L.A. and Pollock, M.L. (1988) Physiological Responses to Walking with Hand Weights, Wrist Weights, and Ankle Weights. Medicine \& Science in Sports \& Exercise, 20, 265-271. https://doi.org/10.1249/00005768-198806000-00009

[7] Mujika, I. (2014) Olympic Preparation of a World-Class Female Triathlete. International Journal of Sports Physiology and Performance, 9, 727-731. https://doi.org/10.1123/ijspp.2013-0245

[8] Foster, C., Hector, L.L., Welsh, R., Schrager, M., Green, M.A. and Snyder, A.C. (1995) Effects of Specific versus Cross-Training on Running Performance. European Journal of Applied Physiology and Occupational Physiology, 70, 367-372. https://doi.org/10.1007/bf00865035

[9] Snyder, A.C., Jeukendrup, A.E., Hesselink, M.K., Kuipers, H. and Foster, C. (1993) A Physiological/Psychological Indicator of Overreaching during Intensive Training. International Journal of Sports Medicine, 14, 29-32. https://doi.org/10.1055/s-2007-1021141

[10] Impellizzeri, F.M., Rampinini, E., Coutts, A.J., Sassi, A. and Marcora, S.M. (2004) Use of RPE-Based Training Load in Soccer. Medicine \& Science in Sports \& Exercise, 36, 1042-1047. https://doi.org/10.1249/01.MSS.0000128199.23901.2F

[11] Foster, C., Florhaug, J.A., Franklin, J., Gottschall, L., Hrovatin, L.A., Parker, S., et al. (2001) A New Approach to Monitoring Exercise Training. The Journal of Strength \& Conditioning Research, 15, 109-115. https://doi.org/10.1519/00124278-200102000-00019

[12] Moreira, A., Kempton, T., Aoki, M.S., Sirotic, A.C. and Coutts, A.J. (2015) The Impact of 3 Different-Length Between-Matches Microcycles on Training Loads in Professional Rugby League Players. International Journal of Sports Physiology and Performance, 10, 767-773. https://doi.org/10.1123/ijspp.2015-0100

[13] Royal, K.A., Farrow, D., Mujika, I., Halson, S.L., Pyne, D. and Abernethy, B. (2006) The Effects of Fatigue on Decision Making and Shooting Skill Performance in Water Polo Players. Journal of Sports Sciences, 24, 807-815. 
https://doi.org/10.1080/02640410500188928

[14] Minganti, C., Capranica, L., Meeusen, R., Amici, S. and Piacentini, M.F. (2010) The Validity of Sessionrating of Perceived Exertion Method for Quantifying Training Load in Teamgym. The Journal of Strength \& Conditioning Research, 24, 3063 3068. https://doi.org/10.1519/JSC.0b013e3181cc26b9

[15] Wallace, L.K., Slattery, K.M. and Coutts, A.J. (2009) The Ecological Validity and Application of the Session-RPE Method for Quantifying Training Loads in Swimming. The Journal of Strength \& Conditioning Research, 23, 33-38. https://doi.org/10.1519/JSC.0b013e3181874512

[16] Minganti, C., Capranica, L., Meeusen, R. and Piacentini, M.F. (2011) The Use of Session-RPE Method for Quantifying Training Load in Diving. International Journal of Sports Physiology and Performance, 6, 408-418.

https://doi.org/10.1123/ijspp.6.3.408

[17] Hartman, M.J., Fields, D.A., Byrne, N.M. and Hunter, G.R. (2007) Resistance Training Improves Metabolic Economy during Functional Tasks in Older Adults. The Journal of Strength \& Conditioning Research, 21, 91-95.

https://doi.org/10.1519/00124278-200702000-00017

[18] Swart, J., Lamberts, R.P., Lambert, M.I., Lambert, E.V., Woolrich, R.W., Johnston, S., et al. (2009) Exercising with Reserve: Exercise Regulation by Perceived Exertion in Relation to Duration of Exercise and Knowledge of Endpoint. British Journal of Sports Medicine, 43, 775-781. https://doi.org/10.1136/bjsm.2008.056036

[19] Coquart, J.B., Eston, R.G., Grosbois, J.M., Lemaire, C., Dubart, A.E., Luttenbacher, D.P., et al. (2010) Prediction of Peak Oxygen Uptake from Age and Power Output at RPE 15 in Obese Women. European Journal of Applied Physiology, 110, 645-649. https://doi.org/10.1007/s00421-010-1524-5

[20] Julius, L.M., Brah, J.S., Wert, D.M. and VanSwearingen, J.M. (2012) Perceived Effort of Walking: Relationship with Gait, Physical Function and Activity, Fear of Falling, and Confidence in Walking in Older Adults with Mobility Limitations. Physical Therapy, 92, 1268-1277. https://doi.org/10.2522/ptj.20110326

[21] De Koning, J.J., Foster, C., Bakkum, A., Kloppenburg, S., Thiel, C., Joseph, T., et al. (2011) Regulation of Pacing Strategy during Athletic Competition. PLoS ONE, 20, e15863.

[22] Borresen, J. and Lambert, M.I. (2009) The Quantification of Training Load, the Training Response and the Effect on Performance. Sports Medicine, 39, 779-795. https://doi.org/10.2165/11317780-000000000-00000

[23] Marcora, S.M., Staiano, W. and Manning, V. (2009) Mental Fatigue Impairs Physical Performance in Humans. Journal of Applied Physiology, 106, 857-864.

https://doi.org/10.1152/japplphysiol.91324.2008 
Submit or recommend next manuscript to OALib Journal and we will provide best service for you:

- Publication frequency: Monthly

- 9 subject areas of science, technology and medicine

- Fair and rigorous peer-review system

- Fast publication process

- Article promotion in various social networking sites (LinkedIn, Facebook, Twitter, etc.)

- Maximum dissemination of your research work

Submit Your Paper Online: Click Here to Submit

Or Contact service@oalib.com 